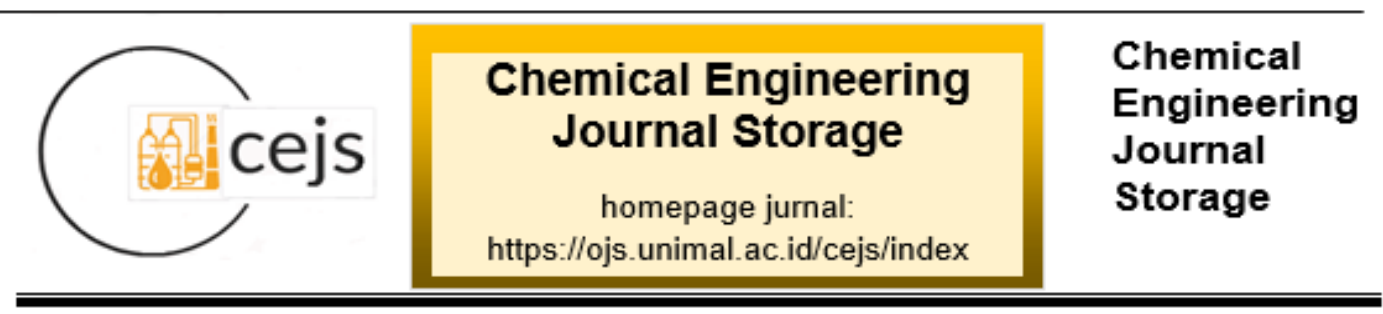

\title{
PENURUNAN KADAR FREE FATTY ACID (FFA) PADA CRUDE PALM OIL (CPO) DENGAN PROSES ESTERIFIKASI MENGGUNAKAN KATALIS ASAM SULFAT $\left(\mathrm{H}_{2} \mathrm{SO}_{4}\right)$
}

\author{
Reza Abdillah Harahap ${ }^{1}$, Azhari ${ }^{1}$, Meriatna ${ }^{1}$, Sulhatun ${ }^{1}$, Suryati $^{1}$ \\ ${ }^{1}$ Jurusan Teknik Kimia, Fakultas Teknik, Universitas Malikussaleh \\ Kampus Utama Cot Teungku Nie Reuleut, Muara Batu, Aceh Utara - 24355 \\ Korespondensi:HP: 085362159499, e-mail: azhari@unimal.ac.id
}

\begin{abstract}
Abstrak
Asam lemak bebas adalah asam lemak yang terpisahkan dari trigliserida, digliserida, monogliserida, dan gliserin bebas. Minyak kelapa sawit merupakan minyak nabati berwarna jingga kemerah-merahan yang diperoleh dari proses pengempaan (ekstraksi) daging buah tanaman Elaeis guinneensis. Tujuan dari penelitian ini adalah menganalisis penurunan kadar asam lemak bebas dari minyak kelapa sawit dengan menggunakan katalis homogen asam sulfat. Proses esterifikasi mereaksikan minyak dan metanol dengan menggunakan katalis asam sulfat. Pengaruh dari berbagai variabel proses seperti waktu reaksi dan persentase massa penggunaan katalis diamati dalam percobaan ini. Penurunan kadar asam lemak bebas, densitas, dan viskositas dianalisa dan dibandingkan dengan Standar Nasional Indonesia (SNI) 01-2901-2006 tentang minyak kelapa sawit mentah (Crude Palm Oil). Kadar asam lemak bebas awal yang diperoleh pada penelitian adalah 10,59\%. Sedangkan penurunan kadar asam lemak bebas setelah dilakukan proses esterifikasi paling bagus yang didapat adalah 2,23\% dengan menggunakan persentase penggunaan katalis 1,4\% pada suhu 60 oC selama 130 menit. Hasil yang diperoleh pada penelitian ini menunjukkan bahwa katalis asam sulfat pekat dapat menurunkan kadar asam lemak bebas yang terkandung didalam minyak kelapa sawit.
\end{abstract}

Kata kunci : Asam lemak bebas, Esterifikasi, Homogen, dan Minyak Kelapa Sawit

\section{Pendahuluan}

Indonesia merupakan Negara dengan berbagai kekayaan alam, salah satunya adalah kelapa sawit. Bedasarkan statistik Direktorat Jendral Perkebunan Indonesia volume dan nilai eksport minyak sawit (CPO) dari tahun 2015-2017 menunjukkan penurunan dari tahun 2015 sebesar 26.476.564 ton menjadi 
24.150.232 ton pada tahun 2016. Diperkirakan hal tersebut terjadi karena banyak nya jumlah konsumsi minyak kelapa sawit dalam negeri.

Saat ini Indonesia merupakan salah satu Negara penghasil CPO terbesar di dunia. CPO merupakan bahan pembuat minyak goreng. Proses pendistribusian minyak sawit kasar di Indonesia dikelola dengan persyaratan mutu yang diatur melalui Standar Nasional Indonesia (SNI). Standar CPO yang digunakan adalah SNI 01-2901-2006 mengenai Minyak Kelapa Sawit Mentah (CPO) yang disusun oleh Badan Standardisasi Nasional (BSN). Salah satu aturan mutu yang menjadi fokus kajian dalam penelitian ini adalah keberadaan asam lemak bebas (ALB). Kadar ALB harus tidak lebih dari $5 \%$ (BSN, 2012).

Beberapa jenis CPO adalah CPO dengan kadar Free Fatty Acid (FFA) < $5 \%$, CPO off grade (minyak kotor) dengan FFA 5-20\%, CPO parit dengan FFA $20-70 \%$, dan Palm fatty acid destilate (PFAD) dengan FFA $>70 \%$ (susanto,2008). Salah satu cara yang dapat dilakukan untuk menghilangkan asam lemak bebas adalah mereaksikan asam lemak bebas dengan alkohol dengan bantuan katalis asam sulfat. Reaksi ini dikenal dengan esterifikasi. Esterifikasi merupakan reaksi antara asam karboksilat dengan alkohol menghasilkan ester dan air. Asam karboksilat yang digunakan dapat berasal dari asam lemak bebas yang terkandung dalam minyak nabati atau berupa distilat asam lemak sawit (DALMs) (Rasyd,2010). Reaksi esterifikasi berlangsung dengan batuan katalis seperti H2SO4, HCL, HF, dan H3PO (Susanto,2008). Dan dalam penelitian kali ini menggunakan katalis asam sulfat yang memiliki konsentrasi sebesar 90\% dengan $\mathrm{KOH}$ yang digunakan sebagai titran untuk menghitung kadar Asam lemak bebas (ALB).

Esterifikasi pada umumnya dilakukan untuk membuat biodiesel dari minyak berkadar FFA tinggi (berangka asam $>5 \mathrm{mg} \mathrm{KOH} / \mathrm{g}$ ). pada tahap ini, asam lemak bebas akan dikonversikan menjadi metil ester. Proses esterifikasi adalah reaksi reversible dimana asam lemak bebas (Free fatty acid/ FFA) dikonversi menjadi alkil ester melalui katalis asam ( $\mathrm{HCl}$ atau umumnya $\left.\mathrm{H}_{2} \mathrm{SO}_{4}\right)$. 
Ketika konsentrasi asam lemak bebas dalam minyak tinggi, seperti dalam minyak CPO dan minyak jelantah (Lotero. 2005).

Alkohol yang paling umum digunakan pada proses esterifikasi adalah metanol dan etanol, terutama metanol, karena harganya murah dan reaktifitasnya paling tinggi (sehingga reaksinya disebut metanolisis). Produk yang dihasil kan (jika menggunakan metanol) lebih sering disebut sebagai metil ester asam lemak ( Fatty acid methyl ester/ FAME), sedangkan jika etanol yang digunakan sebagai reaktan, maka akan diperoleh campuran etil ester asam lemak ( Fatty acid ethyl ester/ FAEE). Dengan minyak berbasis bio (minyak nabati) maka hubungan stoikiometrinya memerlukan $3 \mathrm{~mol}$ alkohol permol TAG (3:1), tetapi reaksi biasanya membutuhkan alkohol berlebih berkisar 6:1 hingga 20:1 (Zhang. 2003)

\section{Bahan dan Metode}

Bahan baku pada penelitian berupa Crude palm oil (CPO) Bahan lain adalah Asam sulfat $\left(\mathrm{H}_{2} \mathrm{SO}_{4}\right)$, Aquadest, $\mathrm{KOH} 0,1 \mathrm{~N}$ Metanol, Indikator phenolphthalein

Penelitian ini terdiri dari tiga tahap yaitu proses preparasi sampel Crude Palm Oil, proses Esterifikasi dan proses Pengujiai. Pengujian pada penelitian ini dilakukan dengan uji asam lemak bebas, densitas dan viskositas. Variasi percobaan dilakukan terhadap Persentasi katalis pada CPO sebesar ( 1\%, 1,2\% dan 1,4\%) terhadap waktu esterifikasi (70, 90, 110 dan 130) menit dan adsorben pada temperatur operasi $120^{\circ} \mathrm{C}$ dengan tekanan konstan

Preparasi sampel CPO dilakukan dengan tahap pemanasan dengan suhu operasi kontan $45^{\circ} \mathrm{C}$.

Proses Esterifikasi dilakukan dengan campuran CPO yang telah dipanaskan ditambahkan pelarut Methanol dan Katalis H2SO4, Campuran di masukkan ke labu leher 3 lalu dipanaskan di hotplate dengan menggunakan kondensor sampai waktu yang di variasikan, lalu dimasukkan kedalam corong pemisah lalu di diamkan 24 jam hingga terbentuk 2 lapisan, diambil lapisan bawah etil ester untuk dilakukan tahap pengujian dengan cara penentuan kadar FFA dengan metode titrimetri, Uji Densitas dan Viskositas. 
3. Hasil dan Diskusi

3.1 Pengaruh Perbandingan Persentasi Katalis (\%) Serta Waktu (Menit) Terhadap Penurunan Kadar Asam Lemak Bebas/ Free Fatty Acid (FFA).

Adapun hasil perbandingan persentasi katalis serta waktu terhadap penurunan kadar asam lemak bebas/ free fatty acid yang dihasilkan dengan menggunakan katalis asam sulfat pekat dengan konsentrasi $90 \%$. Dengan variasi waktu yang berbeda beda dan suhu esterifikasi sebesar $60 \mathrm{oC}$, dapat dilihat pada Gambar 4.1

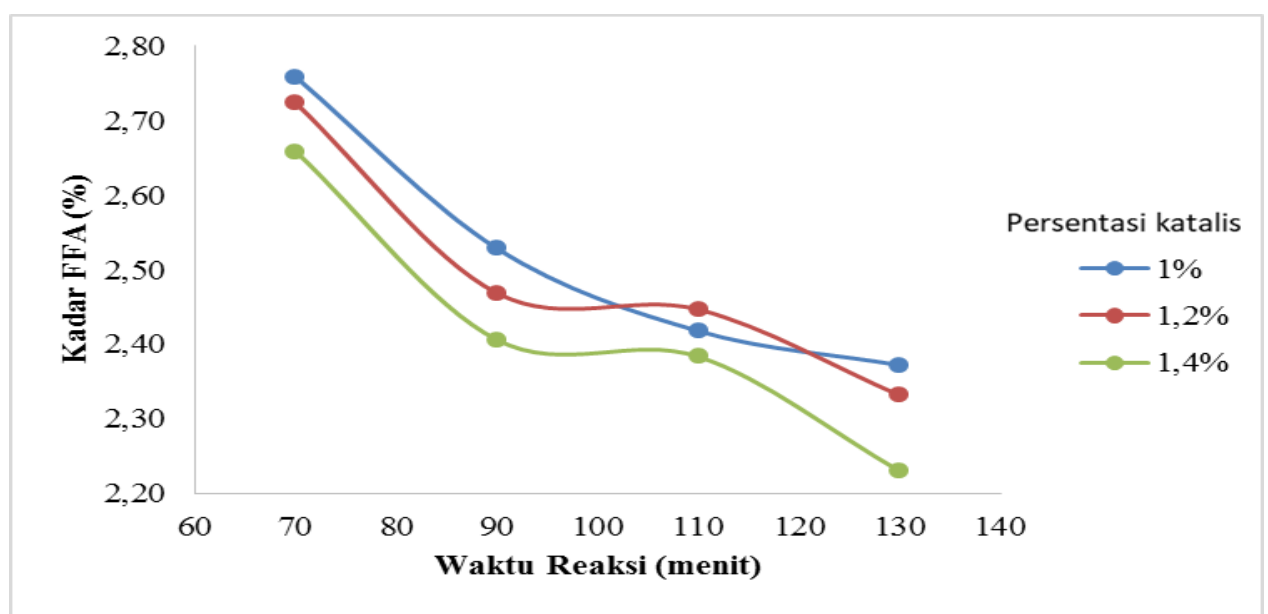

Gambar 4.1 Grafik Hubungan Antara Pengaruh Persentasi Katalis Dan Waktu Reaksi Terhadap Kadar Asam Lemak Bebas/ Free Fatty Acid (FFA).

Bedasarkan Grafik 4.1, dapat dilihat penggunaan perbandingan persentasi katalis mempengaruhi penurunan kadar asam lemak bebas/ Free Fatty Acid yang dihasilkan. Hal ini disebabkan karena penggunaan persentasi katalis dapat mempercepat reaksi sehingga dapat mempecepat terjadinya kesetimbangan reaksi. Penggunaan katalis asam pada reaksi esterifikasi bertujuan untuk menghindari reaksi penyabunan yang timbul apabila reaksi menggunakan katalis basa. Namun katalis asam yang digunakan memerlukan waktu reaksi jauh lebih panjang dibandingkan reaksi katalis basa (Van Gerpen,2004). Menurunnya kadar asam lemak bebas/ Free Fatty Acid juga disebabkan oleh suhu reaksi yang naik turun sehingga kesetimbangan reaksi yang tidak dapat dipertahankan, dan juga dapat disebab kan oleh waktu reaksi yang digunakan. Kondisi terbaik pada penelitian yang dilakukan berdasarkan Gambar 4.1 ialah pada penggunaan persentasi katalis 
1,4\% dengan waktu reaksi selama 130 menit kadar asam lemak bebas/ Free Fatty Acid yang dihasilkan yaitu sebesar 2,23\%.

Menurut Aziz (2007) semakin lama waktu reaksi, kadar FFA yang dihasilkan semakin berkurang. Ini menandakan terjadinya reaksi antara FFA dengan metanol menghasilkan ester. Lamanya waktu reaksi memberikan kesempatan kepada molekul-molekul senyawa untuk bereaksi semakin besar, sehingga FFA yang tersisa semakin berkurang. Kadar Asam lemak bebas/ Free Fatty Acid awal yang didapat yaitu sebesar 10.59\%, sedangkan kadar asam lemak bebas yang didapat setelah dilakukan proses esterifikasi pada Gambar 4.1 dapat dilihat bahwa pada waktu reaksi 70 menit dengan menggunakan persentasi katalis $1 \%$ mengahasilkan kadar asam lemak bebas/ Free Fatty Acid sebesar 2,76\%. Namun, pada waktu reaksi selama 90 menit asam lemak bebas/ Free Fatty Acid yang dihasilkan mengalami penurunan menjadi 2,53\%, begitu juga yang terjadi pada waktu reaksi selama 110 menit kadar asam lemak bebas/ Free Fatty Acid yang dihasilkan mengalami penurunan yaitu sebesar 2,42\% dan pada waktu 130 menit kadar asam lemak bebas/ Free Fatty Acid yang dihasilkan sama dengan pada waktu 110 menit yaitu sebesar 2,37\%.

\subsection{Pengaruh Perbandingan Persentasi Katalis (\%) Serta Waktu (Menit) Terhadap Densitas (gr/ml).}

Pengaruh perbandingan persentasi katalis (\%) serta waktu (menit) terhadap densitas (gr/ml) dapat dilihat pada Gambar 4.2

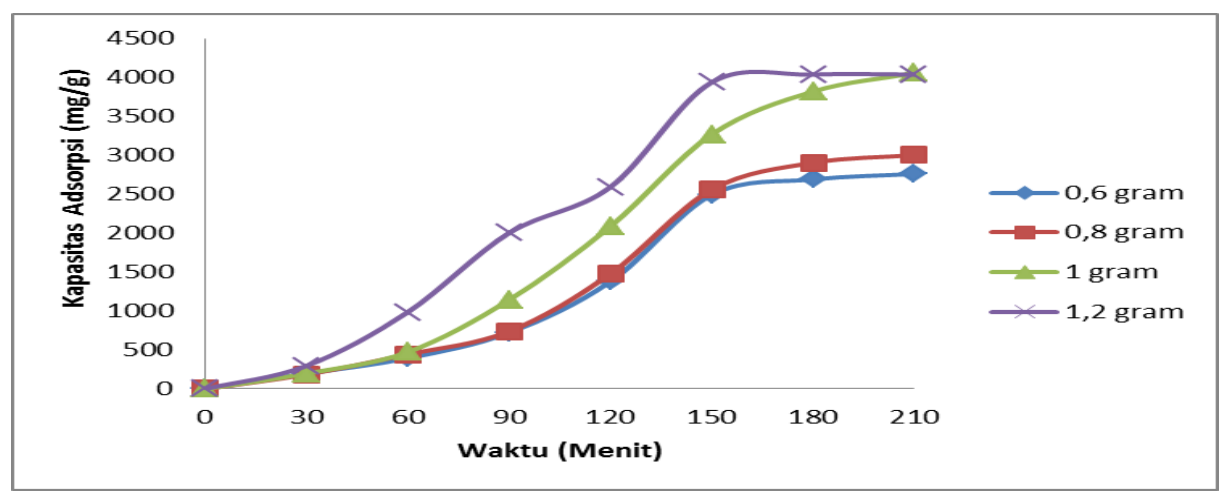


Gambar 4.2 Grafik Hubungan Antara Pengaruh Persentasi Katalis Dan Waktu Reaksi Terhadap densitas (gr/ml).

Kadar densitas awal pada penelitian ini didapat sebesar $1,474 \mathrm{gr} / \mathrm{ml}$, lalu setelah dilakukan proses esterifikasi dapat dilihat pada Gambar 4.2 dengan memvariasikan waktu reaksi 70,90,110, dan 130 menit dengan memperbandingkan persentasi katalis yang digunakan. Pada penggunaan persetasi katalis $1 \%$ didapat densitas sebesar $0,82,0,81,0,80$, dan $0,80 \mathrm{gr} / \mathrm{ml}$. Pada penggunaan persentasi katalis $1.2 \%$ menghasilkan densitas sebesar 0,80, 0,79, 0,78, dan $0,77 \mathrm{gr} / \mathrm{ml}$. Kemudian densitas yang didapatkan pada penggunaan persentasi katalis $1.4 \%$ sebesar $0,79,0,76,0,75$, dan $0,71 \mathrm{gr} / \mathrm{ml}$.

Berdasarkan hasil uji densitas dapat dilihat bahwa penggunaan persentasi katali dan waktu reaksi berpengaruh pada densitas yang didapatkan, nilai densitas pada masing-masing cenderung menurun dan terdapat pada penggunaan persentasi katalis 1\% dengan waktu 110 menit dan 130 menit yang konstan. Hal ini dapat disebabkan karena temperature pada saat menganalisa sampel sama. Pengaruh temperature sampel pada saat pengalisaan sangat berpengaruh pada hasil analisa densitas. Menurut Baroutian (2010) densitas merupakan suatu fungsi dari suhu. Hal ini memiliki arti bahwa setiap perubahan suhu akan menyebabkan perubahan nilai densitas.

\subsection{Pengaruh Perbandingan Persentasi Katalis (\%) Serta Waktu (Menit) Terhadap Viskositas (gr/ml).}

Pengaruh perbandingan persentasi katalis dengan waktu reaksi terhadap viskositas dapat dilihat pada Gambar 


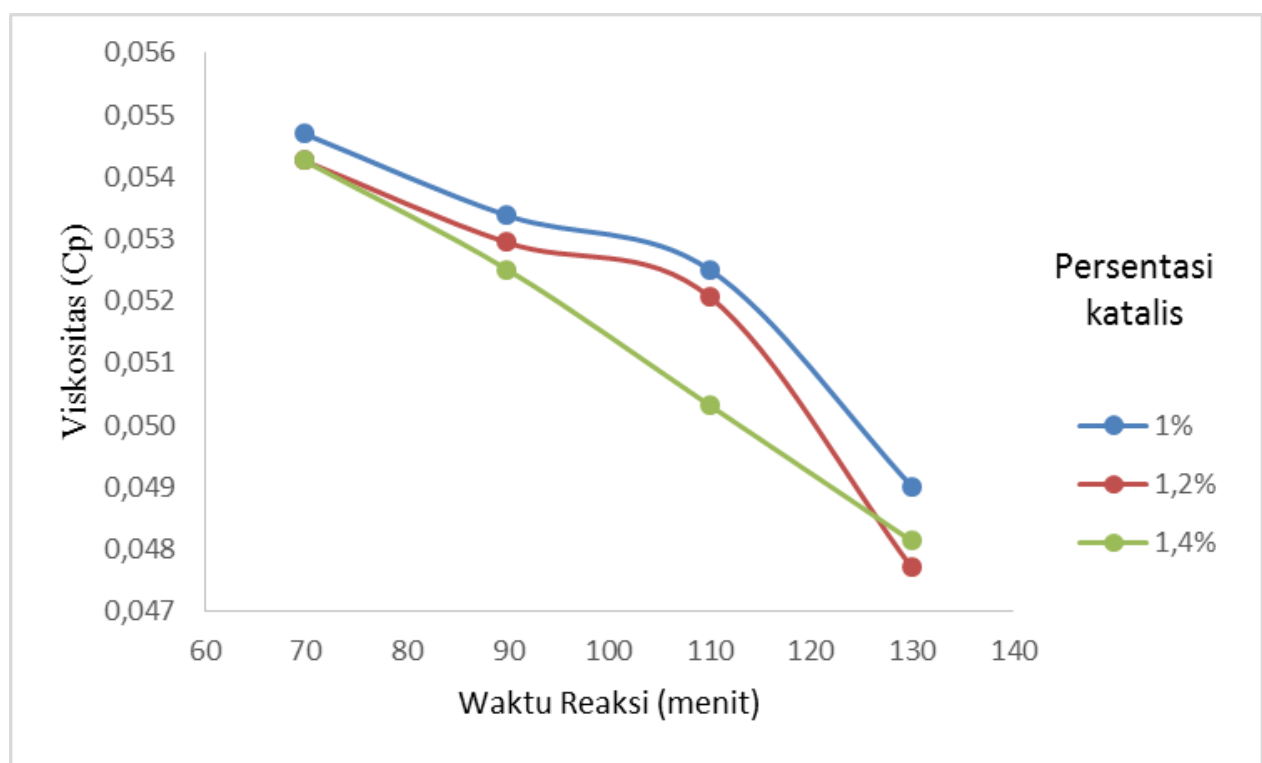

\section{Gambar 4.3 Grafik Hubungan Antara Pengaruh Persentasi Katalis Dan Waktu Reaksi Terhadap Viskositas CPO.}

Kadar densitas awal yang didapatkan pada penelitian ini adalah $0,0875 \mathrm{CP}$ sedangkan setelah dilakukan proses esterikasi dapat dilihat pada Gambar 4.3 pada suhu $60^{\circ} \mathrm{C}$ dengan variabel waktu reaksi selama 70,90,110, dan 130 menit pada perbandingan persentasi katalis $1 \%$ didapat nilai sebasar 0,$0547 ; 0,534 ; 0,0525$; dan 0,049 . Kemudian pada perbandingan penggunaan katalis $1.2 \%$ nilai viskositas yang didapat sebesar 0,$0544 ; 0,0529 ; 0,0521$; dan 0,0477 . Untuk perbandingan penggunaan katalis $1.4 \%$ nilai viskositas yang didapat sebesar 0,0543;0,0525;0,0503 dan 0,0481.

Bedasarkan nilai viskositas yang diperoleh dapat disimpulkan bahwa massa katalis mempengaruhi nilai viskositas yang didapat. Semakin banyak jumlah katalis yang digunakan maka semakin menurun nilai viskositas yang dihasilkan.

\section{Simpulan dan Saran}

Penyerapan FFA dengan proses esterifikasi dengan katalis asam sulfat pada CPO paling baik terdapat pada waktu 130 menit dengan menggunakan persentase massa katalis 1,4\% dengan kadar FFA 2,23\%. Asam sulfat (H2SO4) pekat dengan konsentrasi 90\% yang digunakan sebagai katalis homogen dalam 
proses esterifikasi penurunan kadar asam lemak bebas dapat menurunkan kadar FFA dari $10,59 \%$ sampai $2,23 \%$. Karakteristik penurunan kadar asam lemak bebas yang dihasilkan pada waktu 130 menit dengan persentase katalis 1,4\% yaitu, densitas, 0,71 gr/ml dan viskositas, 0,048 CP. Hasil penurunan kadar asam lemak bebas yang dilakukan telah memenuhi Standart Nasional Indonesia (SNI) 01-2901-2006 tentang minyak kelapa sawit mentah (Crude Palm Oil).

Penelitian ini dapat dilanjutkan denga menggunakan menggantikan katalis asam sulfat pekat dengan jenis katalis homogen yang lainnya untuk mengetahui penurunan asam lemak bebas yang signifikan dalam menggunakan katalis homogen, serta dapat memvariasikan suhu dan waktu.

\section{Daftar Pustaka}

Aziz, Ulum Nurbayati. "Pembuatan Produk Biodisel dari Minyak Goreng Bekas dengan cara Esterifikasi dan Transesterifikasi Valensi 2." (2011): 443-448.

Baroutian, S M.K. "Viscosities and densities of binary and ternary blends of palm oil, palm biodisel, disel fuel at different temperatures." Chemical Society (2010): 504-507.

BSN, Badan Standarisasi Nasional. Standarisasi Minyak Kelapa Sawit. Jakarta, 2012.

Lotero, E and Y Liu. "Synthesis of biodisel via acid catalyis ." Industrial and Engineering Chemistry Research (2005): 5353-5363.

Susanto, BH Nasikin. "Sintesis pelumas dasar bio melalui esterifikasi asam oleat menggunakan katalis asam heteropoli/zeolit." prosiding seminar nasional rekayasa kimia dan proses (2008).

Van gerpen, J Shanks and G knothe. "Biodisel production technology." National renewable energy laboratory (2004).

Zhang, Z. "Preparation of biodisel from waste cooking oil via two step catalyzed process energy convertion and manajemen." (2003): 184-188. 